\title{
TAXABLE STATUS OF FRATERNAL INSURANCE
}

ON THE crest of a long European history, 1 the idea of fraternal benefit societies burst upon the American scene in the hectic years following the Civil War. ${ }^{2}$ Captivated as much by the delusive simplicity of the insurance features as by the mystic aspects of fraternalism, ${ }^{3}$ hordes of poorer Americans shunned the expensive and scandal-reeking intricacies of the standard insurance of that day to form thousands of these associations throughout the country. ${ }^{4}$ Like ordinary fraternal orders, fraternal benefit societies were permeated with a spirit of brotherhood and characterized by a lodge system, ritualism, and representative government. 3 But in addition they adopted as one of their activities the payment of death or disability benefits to members or their dependents. ${ }^{6}$ Few of these original associations have survived, ${ }^{7}$ but

1. For accounts of the growth of European fraternal benefit associations, see Friendly Societies, 6 Encyc. Soc Scrences (1931) 494; Mtulual Aid Sociclics, 11 id. 168, and bibliographies there listed. See also 1 BAcon, Benefir Socretres (4th ed. 1917) 13 et seq. The early development in America is described in 1 id. 24 et scq.; Nichols, Froternal Insurance in the United States: Its Origin, Development, Chorocter, ond Existing Status (1917) 70 AnNals 109.

2. Literature on fraternal insurance is scarce, and much of it is provincial. A good bibliography will be found in 6 ENcyc. Soc. Scresces (1931) 425. The standard treatise on fraternal insurance law is somewhat out of date. BACON, BENEFir SocIETIEs (4th ed. 1917). Two monthly magazines, The Fraternal Field (Cedar Rapids, Iowa) and Tre Fraternal Monitor (Rochester, N. Y.) occasionally contain uceful information.

Throughout this Comment, the abbreviation NFCA, Proczedrwas will be used to refer to the proceedings of the National Fraternal Congress of America.

3. See Nichols, Fratervial Insurance in Yale Irsurance Lectunes (1903-4) 162 The influence of "consciousness of kind" caused by racial, religious, occupational or moral similarity is emphasized in Fraternal Orders, 6 Excrc Soc Sctevces (1931) 423.

4. See Nichols, supra note 1 , at 111. In 1901, an observer vrote: “. . . excepting paper money crazes, history probably affords no parallel to the blind and persistent adhesion which so many people in all parts of the United States have shown to hopelessly unsound schemes of fraternal insurance" Mfeyer, Fratemal Insurance in the Urited States (1901) 17 Ansals 260, at 262.

5. This is still a familiar requirement of state statutes. See, c.g., The Nev York Conference Bill, adopted in substance by most states, reprinted in BASYE, FRATERsiL InsURANCE (1919) $134 \mathrm{ff}$. A few of the reported decisions contain full descriptions of fraternal benefit societies. See especially, Biggs v. Modern Woodmen of America, 82 S. W. (2d) 898, 904 (Mo. 1935) ; Van de Water v. Order of United Commercial Travelers, 77 F. (2d) 331, 332 (C. C. A. 2d, 1935); Mfodern Woodmen of Amerien v. Casados, 17 F. Supp. 763, 766 (D. N. MI. 1937).

6. Then, as now, fraternal benefit societies were organized as voluntary associations without capital stock on a non-profit basis.

7. It has been estimated that of the $\mathbf{3 5 0 0}$ mutual assessment associations organized between 1870 and 1910, no less than 3000 failed after an average life of fifteen years. Praternal Orders, 6 ENCYC. Soc. ScIENCES (1931) 423, 424. Of the 203 large fraternal benefit societies reporting in 1936, only 8 antedated 1871, and only 38 were in existence prior to 1881. 42 Statistics Fraternal Soctettes (1936) 24. 
their places have been filled by countless others, many of which have grown to an astounding size. ${ }^{8}$

From their initial appearance until the present day, fraternal benefit societies have been favored by courts and legislatures alike. The special privileges commonly accorded such associations comprise, broadly, a two-fold exemption: first, from the operation of general insurance laws, and secondly, from all taxes except property taxes. Although the blanket exemption from insurance laws ${ }^{0}$ is counteracted to some extent by special statutory requirements, ${ }^{10}$ interpretative judicial decisions have shielded fraternal societies from many of the burdens placed upon old line companies. A few examples may be cited. Unlike old line policies, fraternal certificates may be made subject to the charter, by-laws, and constitution of the society, and the application for membership may be made part of the insurance contract without being specifically attached.11 Statements ordinarily regarded as representations when made to old line companies are considered warranties if made to fraternal benefit societies. ${ }^{12}$ Where provided by the laws of the society, the defense of suicide is available to the societies despite statutory limitations on its use by commercial companies. ${ }^{13}$ The presumption of death after seven years unexplained absence, though conclusive on old line companies, may sometimes be obviated by a fraternal by-law. ${ }^{14}$ Fraternals are usually exempt

8. E.g., on Jan. 1, 1936, Modern Woodmen of America had $\$ 650,393,463$ worth of insurance in force and 488,523 members; Royal Neighbors of America, $\$ 438,501,224$ of insurance and 609,382 members; Woodmen of the World (Sov. Camp), $\$ 413,081,096$ of insurance (including juvenile), and 362,596 members. 42 Statistics Fraternat. SocieTIES (1936) 13 and 16.

Other relevant statistics as of Jan. 1, 1936: Total insurance in force (including juvenile), $\$ 6,718,679,312$. Total membership, 7,729,530. Total number of lodges, 101,704.

9. The typical statute reads: "Except as herein provided, such [fraternal benefit] societies shall be governed by this article [dealing with fraternal benefit societies] and shall be exempt from all provisions of the insurance laws of this state not only in governmental relations with the state, but for every other purpose, and no law hereafter enacted shall apply to them, unless they be expressly designated therein." See e.g., AzA. Code Anv. (Michie, 1928) §8442. See Fraternal Society Law Assoc. Proceedings (1936) 90 et seq.; Patterson, The Insurance Commissioner in the United States (1927) 127 , n. 29.

10. For a summary of this legislation, see Basye, Fraternal Insurance (1919) 108.

11. See 2 Bacon, Benefir Socteties (4th ed. 1917) $\$ 417$.

12. Gordon v. Royal Neighbors of America, 90 S. W. (2d) 198 (Mo. 1936); Vigil v. American Insurance Union, 37 N. M. 44, 17 P. (2d) 936 (1932); Braddock by Smith v. Pacific Woodmen Life Ass'n, 89 Utah 75, 54 P. (2d) 1189 (1936). 1 BAcon, BENEpTT SocIETIES (4th ed. 1917) $\$ 238$ et seq.

13. Neighbors of Woodcraft v. Westover, 99 Colo. 231, 61 P. (2d) 585 (1936). Contra: Schmidt v. Supreme Ct., United Order of Foresters, 228 Mo. 675, 129 S. W. 653 (1910). See generally Vance, Insurance (1930) 805.

14. Lunt v. Grand Lodge, Ancient Order United Workmen of Iowa, 209 Iowa 1138, 229 N: W. 323 (1930); Mays v. Sovereign Camp, W. O. W., 151 Tenn. 604, 271 S. W. 34 (1925) 40 A. L. R. 1266 (1926). Contra: Shapiro v. Indep. Order Brith Abraham of U. S. A., 246 App. Div. 766, 283 N. Y. Supp. 951 (2d Dep't 1935); Ware v. Grand 
from the penalties for vexatious delays and attorney fees levied by most states upon regular companies.15 Finally, benefits may be forfeited upon failure of the insured to comply with the peculiar requirements of membership, ${ }^{10}$ and a society may refuse to pay to a beneficiary who is not within the class of dependents stipulated in the by-laws. ${ }^{17}$

Aside from these specific concessions to fraternal insurance orders, lack of governmental supervision during the early stages of their development assured to the societies a broad discretion over actuarial policies, problems of organization and the general conduct of their insurance business. Since state legislatures did not require the maintenance of legal reserves, benefit associations could attract prospective members with alluring promises of insurance coverage at fantastically low rates. Similarly, the exemption from taxation was of prime importance to fraternal organizations, since it enabled them to meet the competition of old line companies by reducing pro tanto the cost of the insurance which they could offer to the lower income groups. True, some courts persisted in refusing to treat fraternal benefit societies as charitable or benevolent institutions, ${ }^{18}$ but pressure from fraternalists, who naturally desired advantageous treatment, and from insurance commissioners, who were interested primarily in uniformity, soon resulted in legislation which effected the desired immunity from tax laws. The typical state statute declared every fraternal benefit society organized or licensed thereunder to

Lodge, Bro. of R. R. Trainmen, 152 Wash. 78, 277 Pac. 383 (1929). See VANes, IsisurANCE (1930) 253.

15. The constitutionality of these penalties as applied to old line companies has baen upheld by the Supreme Court. Life \& Casualty Ins. Co. of Tenn. v. AIcCray, 291 U. S. 566 (1934) ; Comment (1934) 48 HARv. L. REv. 319. But since the penalties are purely statutory, they are inapplicable to fraternal benefit societies unless special provision is made. Sovereign Camp, W. O. W., v. Downer, 241 S. W. 228 (Tex. Civ. App. 1922); see cases collected in 1 Couch, Cyclopedia of Insurance Law (1931) 538 el seq.

16. State statutes usually prohibit forfeitures [See 1 Coucr, CrctorrorA or IrssurANCE LAw (1931) §150, n. 6], but these statutes do not apply to fraternal benefit societies. Olsen v. Sup. Council of Royal Arcanum, 205 Mro. App. 260, 224 S. W. 129 (1920) ; Spears v. Indep. Order of Foresters, 107 S. W. (2d) 126 (AIo. 1937); Snyder v. Grand Int'l Brotherhood of Loc. Engineers, 157 AId. 322, 146 Atl. 284 (1929).

A court may sometimes order reinstatement of the member after exhaustion of internal remedies. Pepe v. Afissanellese Soc of Mfut. Aid of Utica, N. Y., 141 Mfisc. 7, 252 N. Y. Supp. 70 (1930). Failure of a member to exhaust his internal remedies may, however, result in abandonment of the policy when the preliminary procedure was stipulated as a condition precedent to recourse to the courts. Easter v. Brotherhood of American Yeoman, 172 Mo. App. 292, 157 S. W. 992 (1913). See generally 1 Coucr, Cyclofadr of INSURANCE LAW (1931) §266.

17. Ginsberg v. Butler, 217 Calif. 467,19 P. (2d) 790 (1933); Coffman v. Security Benefit Ass'n, 131 Kan. 328, 291 Pac. 753 (1930); Papp v. Grand Lodge A. O. U. W., 116 N. J. L. 156, 182 Atl. 876 (1936). Nor may the statutory restrictions be vaived by a clerk of the fraternal society. Modern Woodmen of America v. Comeaux, 79 Kan. 493, 101 Pac. 1 (1909).

18. Ifany of these decisions arose in connection with property taxes. See, e.g., State Council C. K of Ill. v. Board of Review, 198 Ill. 441, 64 N. E 1104 (1902); Rogal Highlanders v. Nebraska, 77 Neb. 18, 108 N. W. 183 (1906). 
be a charitable and benevolent institution, and as such its funds were exempt "from all and every state, county, district, municipal and school tax other than taxes on real estate and office equipment." 18

When fraternal benefit societies were first formed and the distinction between the two types of insurance was clear, the favored treatment accorded fraternal orders was justified on various grounds. The exemption from general insurance laws was founded on the notion that fraternals were so generically dissimilar from old line companies as to merit different treatment. ${ }^{20}$ It was pointed out that, since the societies were truly representative, the members being both insurers and insured, they could be relied upon to govern their own affairs with a minimum of external interference. ${ }^{21}$ If they chose to include harsh provisions and unreasonable forfeitures in their insurance certificates, and even if their actuarial policies were basically unsound, the public at large would be none the worse off, for no one would be injured but the members themselves. In like respect, the immunity from taxation could be rationalized on the basis of the non-profit aspect of fraternal organizations whose primary object was to indemnify the members' dependents for their loss. ${ }^{22}$ More convincing, however, was the rarely made argument that fraternal benefit societies served a useful and unique function in the insurance field. By offering low cost insurance to those of moderate means, they afforded protection which the members could not otherwise receive and which should therefore not be jeopardized by burdensome taxation. $^{23}$

But, while the special privileges originally granted to fraternal organizations could not be open to serious criticism during the early stages of their development, gradual and far reaching changes in fraternal insurance prompt a reconsideration of the propriety of such distinctive treatment in the light of the function presently performed by benefit societies and the effect of the increasing infiltration of old line principles into the entire fraternal field.

The gradual transformation of fraternal insurance to an approximation of that provided by old line companies may be ascribed to various factors. Most important is the change in actuarial policy necessitated by the inadequacy of the methods originally adopted by fraternal insurers. As first conceived, benefit payments were regarded as nothing more than a convenient method of giving tangible expression to the benevolence inherent in fraternal orders. Payment was made by some form of post-mortem assessment, the holder

19. See N. Y. Conference Bill § 30; Basye, Fraternal Insurance (1919) 134, 154.

20. See Northwestern Mutual Life Ins. Co. v. Wisconsin, 247 U. S. 132, 140 (1918); Van De Water v. Order of United Commercial Travelers, 77 F. (2d) 331, 332 (C. C. A. 2d, 1935).

21. Biggs v. Modern Woodmen of America, 336 Mo. 879,82 S. W. (2d) 898 (1935).

22. Folts v. Globe Life Ins. Co., 117 Neb. 723, 223 N. W. 797 (1929); Pennsylvania v. Girard Life Ins. Co., $305 \mathrm{~Pa}$. 558, 158 At1. 262 (1932).

23. Brown v. Steckler, 40 N. D. 113, 168 N. W. 670 (1918). 
of a benefit certificate customarily receiving the proceeds of a flat assessment upon all of the surviving members. ${ }^{24}$ Thus, instead of continually keeping on hand enough assets to cover the contingent liability of its outstanding policies as calculated by actuarial tables, each society relied upon the members' contributions to cover losses as they occurred. While the post-mortem assessment system, by reason of its low operating costs and mortality experience, afforded pure insurance protection at the cheapest possible rates when the bulk of the members were still young, assessments became more frequent and burdensome as the mortality rate increased with the advancing age level of the society. This burden fell with particular weight upon the more youthful members, who, because of their lower mortality experience, paid a higher price for their insurance than was warranted by the protection they received. Since it was cheaper for this class to form a new society than to join an established one, the cycle of failures was enormous. ${ }^{25}$ Only the strong fraternal attacliments and the natural rise in the average longevity of the population prevented even more disastrous results. ${ }^{28}$

Distrust of the old line companies, particularly as a result of the Armstrong investigation, ${ }^{27}$ coupled with the general unavailability of cheap insurance, directed the energies of fraternalists toward reform rather than complete abandonment of insurance features. ${ }^{28}$ But faith in the assessment principle confined most of the first reforms to variations of the original unsound scheme. Instead of the flat post-mortem assessment, something of a reserve was accumulated by periodical ante-mortem assessments, graded according to age of entry, or according to the present age of individuals or groups within the society. While this system is still in use, particularly among the smaller societies, ${ }^{29}$ fraternalists have generally realized that, despite the low yearly cost, the assessment method is practically unsuited for progressive risks. ${ }^{30}$

24. For a detailed description of the problems arising from use of this method, see Nichols, supra note 1, at 111 et seq.; NicHors, supra note 3, at 171 et seq.; BASrE, FraTERNAL INSURANCE (1919) 41 et seq.

25. See notes 7 and 24 , supra.

26. See Fraternal Orders, sipra note 3.

27. See Report of N. Y. Joint Coararttee on Investigation of Ltfe Imisuraitice (1906).

28. For a description of the variety of schemes under this heading, see (1931) 39 Fraternal Field No. 1, p. S. The power of the society to readjust rates was upheld by the Supreme Court in Royal Arcanum v. Green, 237 U. S. 531 (1915).

29. Some states forbid "pure" assessment companies and restrict the use of this method to fraternal orders. See Patterson, The Insuraxice Cossussstorieg in the United States (1927) 128.

30. The rapid growth, and the subsequent failure, of fraternal benefit societies at the turn of the 19th century has often been attributed to their unsound rates. See, e.g. Patterson, The Distribution of Wage-Earner's Life Insurance (1935) 2 LAW \& CosTEArP. Pвов. 3 at 7. 
As a result of these deficiencies, many societies have adopted the protective features long characteristic of old line insurance. Chief among these has been the accumulation of a reserve in which the society's assets will be equal to its matured liabilities, i.e., the society will be able to pay all of its promised benefits without increasing the rates of assessment or the premiums of its members. ${ }^{31}$ On the proved assumptions that death rates can be determined in advance by mortality tables, and that money can be invested to yield a minimum rate of interest, the Uniform Fraternal Insurance Bills, adopted by most of the states between 1910 and $1915,{ }^{32}$ aimed to place fraternal benefit societies on a legal reserve standard based upon some mortality table representing their own experience. ${ }^{33}$ This necessitated an upward readjustment of rates and reclassification of certificates-a process of reorganization which proved to be a heavy drain upon the societies' resources and from which most of them have but recently emerged. Most important fraternals are now run on the same legal reserve system as old line companies, except for a slight difference in mortality tables and interest rates. ${ }^{34}$

Contemporaneous with the transformation of rate structures, there occurred a corresponding multiplication of the types of insurance offered by fraternal orders. An early advance over the original haphazard system, whereby the beneficiary was merely entitled to the variable proceeds of a post-mortem assessment, was the specification of a definite sum in the insurance certificate, although this sum was of course subject to the ability of the society to raise the stipulated amount. ${ }^{35}$ But as old line insurance gradually penetrated the low cost field to compete with the fraternals, more far reaching alterations were soon required. ${ }^{36}$ The old line companies have invaded the domain of low cost life insurance by means of small monthly premium

31. Some of the statutes calling for this requirement are collected in PATrERSON, The Insurance Commissioner in the United States (1927) 128.

32. Most states have now adopted either the original "Mobile" Bill of 1910 or the modified version of 1912, known as the "New York Conference Bill." The text of the latter bill is reprinted in BASYe, Fraternal Insurance (1919) 134 et seq., followed by an analysis on 156 et seq. See also 13 NFCA, ProceEdings (1926) 75.

33. Comparative tables in (1931) 39 Fraternal Fiesd No. 2, p. 7 indicate that fraternal mortality tables are lower than the American Experience table used by old line companies. See also Basye, Fraternal Insurance (1919) 91 ; 42 Statistics FraTERNAL SOCIETIES (1936) 230 et seq.

34. Of the 55 largest fraternal benefit societies in 1936, only six were operated on a non-legal reserve basis. (1936) 44 Fraternal Field No. 5. For a description of the powers of insurance commissioners with respect to societies which fail to conform to the statutory standards, see Patterson, The Insurance Commissioner in the UNited States (1927) 127 et seq.

35. See Basye, Fraternat Insurance (1919) 47.

36. The competitive trend is indicated by the following table showing the amount of insurance of various types in force in the United States (figures in millions of dollars): 
policies $^{37}$ and rate reductions attendant upon a revision of their antiquated mortality tables.8 They are now able to offer insurance protection at rates no higher than the fraternals and without limitations as to classes of beneficiaries.39. Industrial insurance, despite its relatively high cost, has spread spectacularly since the war. ${ }^{40}$ Group insurance has been developed by numerous employers eager to secure a cheaper method of retaining the loyalty of their employees than by increasing their wages.12 And state systems, like the Massachusetts Savings Plan, have provided cheap protection without ritualism. ${ }^{12}$

Because of the competition created by these numerous insurance schemes, hardly a type of insurance protection has escaped imitation in fraternal circles. Most of the large fraternal benefit associations now issue both term and whole life insurance, with either level or step rate premiums, as well as endowments and juvenile policies. They offer in addition, most of the standard attractions of old line insurance: non-forfeiture and dividend provisions, cash surrender values, paid up insurance values and extended insurance values..$^{43}$ The original list of eligible beneficiaries has been expanded

\begin{tabular}{rccr}
\hline Year & Industrial & Fraternal & Group \\
1880 & 20 & not available & + \\
1885 & 144 & not available & + \\
1890 & 428 & 2,625 & + \\
1895 & 820 & 4,390 & + \\
1900 & 1468 & 5,937 & + \\
1905 & 2310 & 8,150 & + \\
1910 & 3179 & 9,563 & + \\
1915 & 4432 & 8,694 & 99 \\
1920 & 7121 & 8,879 & 1,662 \\
1925 & 12611 & 9,770 & 4,299 \\
1930 & 18275 & 8,964 & 9,910 \\
1935 & 18298 & 6,183 & 10,503
\end{tabular}

This table is reproduced from Myers, The Effect of the Social Sccurily Act on the Life Insurance Needs of Labor (1937) 45 J. PoL. EcoN. 681, 682.

37. See Fraternat Momitor, Consolidated Chast of Insuratice Orgazization (1937).

38. See Thompson, Net Cost of Life Insurance Contracts (1932) 161 Amizis 65.

39. Even fraternalists admit this. See 10 NFCA Proceronacs (1923) 393.

40. See Table, cited note 36 supra.

41. See Hedges, Labor's Interest in Group Insurance (1935) 2 LAW \& ConTEass.

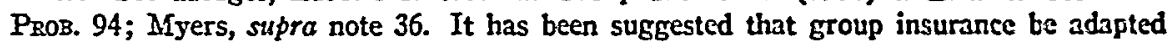
to fraternal benefit societies. 13 NFCA, Proceenings (1926) 131, 271, 346. See generally Graham, Group Insurance (1932) 161 Ansals 40.

42. For a brief summary of the Massachusetts System, see Patterson, The Distribution of Wage-Earner's Life Insurance (1935) 2 LAW \& Conteur. Pron 3, at 8. For more detail, see Berkian, The Massachusetts Systeas of Savings Banis Life IbisuzANCE (Bureau of Labor Statistics Bull. No. 615, 1935). New York has secently instituted a similar system. N. Y. Times, March 17, 1938, p. 1, col. 1; id., April 7, 1938, p. 30 , col. 1 .

43. For a list of the various types of certificates offered by some of the larger societies, see (1931) 39 Fraternai Fiedd No. 9, p. 11. See also, Taylor, Forms of Life 
widely by statute.44 The trend toward "commercialization" of fraternal insurance is well illustrated by some of the provisions of the new uniform legislation suggested by the fraternals in the 1929 Rochester Bill: Societies are to have the power to issue any type of certificate they clesire; members may name anyone as beneficiary; and certificates may be issued with or without medical examination, according to the wishes of the society. 45

These radical changes in insurance features have not intensified the fraternal aspect of benevolent organizations. On the contrary, the inevitable decline of the lodge and its ritual as a result of modern forms of amusement and increased social mobility has reduced the fraternalism of the former societies to a comparatively negligible quantity. ${ }^{46}$ True, charitable and welfare activities are still extensive. ${ }^{47}$ But on the whole, insurance, originally a mere adjunct, has come to be the major raison d'être of fraternal benefit societies. Because of the great variety of insurance contracts and the decline of the lodge as a selling medium, highly trained paid solicitors have become commonplace. ${ }^{48}$ Even a national advertising campaign has recently been suggested. ${ }^{48}$ When fraternalists speak of "reviving" the lodge, it is often more for the purpose of acting as a collection agency than as a social club. ${ }^{50}$

The result of this manifold process has been to obliterate all the peculiar characteristics of fraternal insurance except the absence of profit ${ }^{61}$ and the so-called "open contract" provision ${ }^{52}$ whereby the society reserves the privilege of readjusting rates if the future so demands. ${ }^{53}$ And as the distinguish-

Insurance Organizations (1931) 39 Fraternal Field No. 1, p. 18; Huebner, Life INsurance (1926) 280 et seq.; 42 Statistics Fraternal Socteties (1936) 7.

44. For a complete tabulation of all the state statutes, see Brummund, Eligible Bcncficiaries of Fraternal Benefit Societies (1935) 46 FrATERNAL MonItor No. 8, p. 18; FrAternal Society Law Assoctation, Proceedings (1932) 116.

45. For a transcript of these suggested amendments to the New York Conference Bill, see (1929) 40 Fraternal Monitor No. 2.

46. Nowhere is this better reflected than in the discussions of the fraternalists themselves. See, e.g., 12 NFCA, Proceedings (1925) 428; 13 id. (1926) 193; 15 id. (1928) 288. See also Fraternal Orders (1931) 6 Encyc. Soc. Sciences 423, 425.

47. See Fraternal Society Law Assoctation, Proceedings (1935) 83.

48. Taylor, Provision for Expenses (1932) 40 Fraternal Field No. 2, p. 7; Knight, Fraternal Life Insurance (1927) 130 ANNALs 97. But the smaller societies still rely in good part upon informal solicitation. See N. Y. Times, Jan. 28, 1938, p. 3, col. 1.

49. See (1933) 41 Fraternal Fied No. 11, p. 9.

50. See, e.g., (1931) 39 Fraternal Fiesd No. 1, p. 5 ; (1938) 46 id. No. 3, p. 14.

51. See, e.g., Van de Water v. Order of United Commercial Travelers, 77 F. (2d) 331,332 (C. C. A. 2d, 1935).

52. So closely is the "open contract" idea associated with fraternal insurance that one court has recently held that a fraternal benefit society cannot issue a policy specifying an unchangeable rate of cost. Ancient Order of United Workmen of Kansas v. Hobbs, 136 Kans. 708, 18 P. (2d) 561 (1933). "Open contract" provisions permit far-reaching readjustments in rates. Jenkins v. Talbot, 338 IIl. 441,170 N. E. 735 (1930). This system is said to have the advantage of eliminating expensive receivership proceedings when insolvency threatens. See (1932) 40 Fraternat Fiedd No. 10, p. 5.

53. The fraternalists themselves have argued that when a reinsurer of an insolvent old line company assesses liens against all of the policies of that company, the distinction 
ing features between the two types of insurance have disappeared, legislatures, insurance commissioners, and courts have struggled with the problem of how to administer the public policy in favor of fraternals without thereby affording them a preferential treatment which their anomalous status no longer merits. The typical complication arises where an association with an historical background as a fraternal benefit society continues, if only perfunctorily, to observe the ritualistic requirements, but issues a variety of insurance certificates which are traditionally old line in character.

When the issue has concerned the right of a particular insurer to an exemption from general insurance laws, the courts have arrived at a fairly workable solution to the problem. The controversy may arise in several ways. For instance, the benevolent status of a fraternal organization may be raised as a defense to an action by a certificate holder who seeks to predicate his recovery upon a rule of general insurance law. In this event, the courts will usually hold that if the particular certificate in issue is of a type commonly regarded as fraternal, the beneficiary may not inquire into other uliro vires transactions of the association, but must abide by the usual exemption granted to fraternal groups. ${ }^{54}$ But if the association has edged into the old line field and the particular contract of insurance is unauthorized, courts are more inclined to favor the beneficiary and apply the general insurance rule. Thus, where the policy sued upon is not strictly within the powers of a fraternal benefit society, e.g., when the beneficiary is not within the statutory class, or the type of insurance is unauthorized by local statute, it is generally held that the insurer who issues an ultra vires certificate must take the consequences of the non-availability of certain defenses. ${ }^{.5}$ Different problems are encountered when the character of a benefit society is raised, not in an action on a certificate, but rather in a mandamus suit to obtain a license or an injunction suit to restrain its revocation. In such cases, the courts uniformly examine the entire course of the fraternal's business and grant or refuse the license according to whether or not the insurer has confined its activities to the fraternal field. 50

between "open" and "closed" contracts is reflected only in the change of management. See (1931) 39 Fraternal Fiesd No. 1, p. 8. A recent Colorado statute [1933 Session Laws, ch. 112] applies the "open contract" technique to old line policies. For a description of its implications, see (1931) 39 Fratersal Field Noo. 3, p. 5.

54. Supreme Forest Woodmen Circle v. Bowen, 180 Olla. 534, 71 P. (2d) 480 (1937). The responsibility for penalizing unauthorized acts may be thrust upon the legislature. Westerman v. Supreme Lodge, K. P., 196 MO. 670, 94 S. W. 470 (1906). Or the remedy may lie in dissolution. See Kolesar v. Slovak Evangelical Union, 122 Pa. Super. 318, 323, 186 At1. 302, 304 (1936). See generally 8 Coucr, Cyczopedu or Irsuratice (1929) $\S 2038$.

55. Sovereign Camp, W. O. W. v. Lawson, 52 Ga. App. 345, 183 S. E. 137 (1935); Wilhelm v. Security Benefit Ass'n, 104 S. W. (2d) 1042 (Afo. 1936); Alodern Order of Praetorians v. Bloom, 69 Okla. 219, 171 Pac. 917 (1918); but see Supreme Forest Woodmen Circle v. Bowen, 180 Okla. 534, 71 P. (2d) 480 (1937); Marcus v. Heralds of Liberty, $241 \mathrm{~Pa} .429,88$ Atl. 678 (1913).

56. State ex rel. Supreme Lodge K. P. v. Vandiver, 213 AIo. 187, 111 S. W. 911 (1908). See also National Colored Aid Society v. State, 208 Ind. 380, 195 N. E 240 
But even though the courts have to a large extent resolved the problems centering around the application of general insurance laws, the attack on the more important problem of tax exemption has met with indifferent success. As the trend toward "commercialization" of fraternals gathered momentum, and as the post-war expansion of government activity accentuated the need for increased sources of state revenue, hundreds of bills were introduced in the legislatures for the purpose of subjecting fraternals to the taxes ordinarily applicable to insurance companies. ${ }^{57}$ Unable to buck the powerful "unpaid" lobbies of the fraternals, the great majority of these bills were defeated, and most of the successful ones were later repealed. ${ }^{58}$ It became increasingly clear to those most interested in seeing fraternals taxed that their best hope lay in action by state insurance commissioners. ${ }^{\text {bo }}$ Consequently the courts have been deluged with recent cases involving attempts by commissioners to treat the more extensive fraternal benefit societies as ordinary life insurance companies for purposes of taxation. Concededly test cases, they have usually arisen in one of three ways: (1) The insurance commissioner has brought suit for the taxes. Usually he has claimed taxes for the year immediately preceding or for some slightly longer period, but in many recent instances he has demanded delinquent taxes for a period as long as 25 years, together with interest, attorneys' fees, and penalties for nonpayment. ${ }^{60}$ (2) The insurer has applied for a writ of mandamus or a

(1935) (information by district attorney); In re Henry City Mut. Burial Ass'n, 229 Mo. App. 300, 77 S. W. (2d) 124 (1934) (denial of reincorporation); Independent Order of Puritans v. Brown, 229 S. W. 939 (Tex. Civ. App. 1921) (failure of foreign fraternal society to obtain domestic license). Cf. City of Trenton v. Humel, 134 Mo. App. 595, 114 S. W. 1131 (1909); Tobin v. Estes, 79 S. W. (2d) 550 (Tenn. 1935).

57. See annual reports on statutory legislation in NFCA, ProceEdrngs; Fraternal FIELD; and FraterinaI MONITOR.

58. The methods of fraternalists are graphically pictured throughout the Proctennas of the NFCA. See, e.g., 10 NFCA, Proceedings (1923) 113 et seq.; 13 id. (1926) 189; 14 id. (1927) 28.

59. The history in Iowa is illuminating. In 1933, the Brookings Institution Report on Iowa State Government [II SuRvey of Administration In Iowa (1933) The Revenuc System] recommended, as one means of increasing state revenue, subjection of fraternal benefit societies to regular premium taxes. As a result of effective lobbying [called a "campaign of education" in (1933) 44 FRATERNAL MoNITOR No. 4, p. 13; a $\$ 25$ contribution was asked from every society doing business in Iowa] by the Hawkeye State Fraternal Congress and the Iowa Fraternal Congress, the measure failed to pass, although at the same time the revenue statute levied an individual net income tax, corporation net income tax, and a retail sales tax. (1934) 42 Fraternal Field No. 3, p. 5. In 1936, the insurance commissioner demanded regular premium taxes for $1935,2 \frac{1}{2} \%$ from foreign societies and 1\% from domestic societies. (1936) 44 Fraternal Freld No. 4, p. 5. This resulted in litigation in state and federal courts. Sovereign Camp, W. O. W. v. Murphy, 17 F. Supp. (S. D. Iowa 1936) 650; Yeoman Mut. Life Ins. Co. v. Murphy, 275 N. W. 127 (Iowa 1937). A similar cycle is discernible in Tennessee and Alabama.

60. Missouri v. Homesteaders Life Ass'n, 16 F. Supp. 69 (W. D. Mo. 1936), aff'd, 90 F. (2d) 543 (C. C. A. 8th, 1937); Modern Woodmen of America v. State, 193 Ark. 458, 103 S. W. (2d) 38 (1937); Royal Neighbors of America v. State $e x$ rel. Read, 72 P.

(2d) 325 (Okla. 1937). 
mandatory injunction to compel the insurance commissioner to grant a license which had been refused for nonpayment of taxes. ${ }^{01}$ (3) The insurer has brought injunction proceedings, in either state or federal courts, to restrain the commissioner from collecting taxes. ${ }^{02}$

In these cases, the insurance commissioners have invariably argued that the metamorphosis of the particular insurer deprives it of the benefit of an exemption based upon the admittedly valid statutory distinction between fraternal benefit societies and old line companies. In support of this reclassification, they usually present a detailed picture of the transformation of fraternal insurance, special emphasis being placed upon the tremendous organizations, large salaries, trained solicitors, imitation of old line policies, decline of the lodge system, abuse of the representative form of government, and the expansion of eligible classes of insured and beneficiaries.s

Fraternals have countered these contentions, point for point: Mere size has no bearing, because the issue is one of organization and operation. The payment of salaries is irrelevant, for even charities find it necessary in the interest of efficiency. The desire to attain actuarial solvency, the increasing size and complexity of the societies, and the requirement that members must consent to statutory changes have all necessitated the employment of paid solicitors. Since the societies are both insurers and insured, there can be no such thing as "profit;" and in any event the pertinent criterion is merely whether the association is "organized for profit." The contention that the societies lost their fraternal character when they began to operate on a reserve and ceased making post-mortem assessments is belied by the statutory requirements of a stated reserve in order to assure actuarial solvency. The imitation of old line policies is said to be authorized in many cases; and, where unauthorized, it is subject to timely objections by the insurance commissioner or the attorney-general, who could refuse to approve the certificates or to grant a license, or require dissolution of the society. The requirements of a lodge system are said to be incidental and therefore ful-

61. Homesteaders Life Ass'n v. Murphy, 275 N. W. 146 (Iowa 1937); Yeoman Xfut. Life Ins. Co. v. Mfurphy, 275 N. W. 127 (Iowa 1937).

62. Sovereign Camp, W. O. W. v. Miurphy, 17 F. Supp. 650 (S. D. Iowz 1936); Modern Woodmen of America v. Casados, 17 F. Supp. 763 (D. N. M. 1937). Beesuse of the comparatively large sums usually involved, the familiar method of suing for return of taxes already paid has not been followed. It is said that the consequences of paying these sums or of the revocation of the licenses if not paid, would be so disastrous as to render the remedy at law inadequate. See Sovereign Camp, W. O. W. v. Murphy, stspro at 652 .

63. This has been the general line of argument in all of the following cases: Modern Woodmen of America v. Casados, 17 F. Supp. 763 (D. N. MC. 1937) ; Sovereign Camp, W. O. W. v. MLurphy, 17 F. Supp. 650 (S. D. Iowa, 1936) ; State of Missouri v. Homesteaders Life Ass'n, 16 F. Supp. 69 (W. D. MYo. 1936); Alodern Woodmen of Amerien v. State, 193 Ark 458, 103 S. W. (2d) 38 (1937) ; Homesteaders Life Ass'n v. Mrurpby, 275 N. W. 146 (Iowa 1937); Royal Neighbors of America v. State ex rel. Read, 72 P. (2d) 325 (Okla. 1937). 
filled by compliance with the barest formalities. As long as the essentials of representative government remain, the self-perpetuation of a few officers is wholly immaterial. ${ }^{64}$

With surprising unanimity, the courts have accepted the fraternal viewpoint. ${ }^{65}$ To do otherwise, they have pointed out, would mean penalizing the fraternals for having instituted a system of sound rates and maximum protection. Although they recognize that many of the reasons for granting the exemption no longer exist, and that the legislatures have exempted fraternal societies from many of the burdens imposed upon insurance companies while at the same time permitting them to carry on an old line insurance business, it is said that the situation may be altered, if at all, by legislative action, not by judicial or administrative pronouncement. ${ }^{.68}$

Questionable indeed is the rationale behind some of these decisions. Of course, where commissioners have made such excessively harsh demands for back taxes that compliance by any society would spell certain ruin, there can be no question that recovery of such an amount would be a flagrant injustice to the present membership. It would require them to bear burdens which would otherwise have fallen upon those members who had received insurance protection for years past at a time when the state unquestionably recognized the right of such certificate holders to a general immunity from taxationt. In such cases, the courts have treated the prior construction of administrative officials as a form of estoppel against the state. ${ }^{.7}$

But these considerations appear to be inapplicable where the society has materially altered the type of business from that which entitled it to the exemption and the attempt is made to collect taxes only for the immediately preceding year. Under such circumstances, the wide discretion customarily

64. See cases cited note 63, supra.

65. In all of the cases cited in note 63, supra, the decision was in favor of the fraternal benefit society. Only in Woodmen of the World v. Casados, 21 F. Supp. 989 (D. N. M. 1938) have fraternals been declared subject to premium taxes, but this decision was predicated upon a special statutory provision. See note 75 , infra.

66. See especially the opinion in Modern Woodmen of America v. Casados, $17 \mathrm{~F}$. Supp. 763 (D. N. M. 1937); Sovereign Camp, W. O. W. v. Murphy, 17 F. Supp. 650 (S. D. Iowa 1936); Modern Woodmen of America v. State, 193 Ark. 458, 103 S. W. (2d) 38 (1937). And where the legislature has decreed a tax, the court would not interfere beyond inquiring into its arbitrariness. Modern Woodmen of America v. Casados, 21 F. Supp. 989 (D. N. M. 1938).

67. Modern Woodmen of America v. Casados, 17 F. Supp. 763 (D. N. M. 1937); Homesteaders Life Ass'n v. Murphy, 275 N. W. 146 (Iowa 1937) ; Royal Neighbors of America v. State ex rel. Read, 72 P. (2d) 325 (Okla. 1937). It is generally held that the state's settled practice in collecting revenue from insurance companies over an extended period should not be disturbed without the assignment of compelling reasons. N. Y. Life Ins. Co. v. Burbank, 209 Iowa 199, 216 N. W. 742 (1927). Notice and a hearing are customarily required before revocation of permits. PATTERSon, The InsurANCE Commissioner in the United States (1927) 382 et seq. It has been held that a state license to do business in the granting state makes a prima facie case that the insurer is a fraternal benefit society. Olsen v. Supreme Council, R. A., 205 Mo. App. 260, 224 S. W. 129 (1920). 
exercised by insurance commissioners should extend to what would seem to be a peculiarly administrative problem-the determination of when a fraternal benefit society has ceased to be such. ${ }^{\text {cs }}$

Most of the standard fraternal "policy" objections to taxation seem to miss the mark. It is claimed that the imposition of a tax would involve administrative difficulties because the fraternal society did not include the tax in its rate readjustment. ${ }^{69}$ But this is hardly a major consideration, since timely notice of the levy is generally given, and the readjustment would be essentially similar to that required of old line companies in allowing for payment of taxes. The oft-advanced contention that taxation would discourage the concededly charitable activities of fraternal orders seems unduly pessimistic since the customary segregation of insurance and charitable funds would prevent taxation of purely benevolent functions. ${ }^{70}$ More forceful is the seldom-made argument that, if a distinction between old line and genuine fraternal insurance is in accord with public policy, it would be inequitable to penalize societies partially indulging in old line insurance by taxing their entire activities, whether through a premium or income tax. To overcome the obstacle, however, appropriate action might be taken against ultra vires activities or societies might be taxed only in proportion to their unauthorized insurance. To a limited extent, the latter method was adopted in a recent Iowa case, where it was held that an ordinarily taxable mutual life insurance company is not required to pay a premium tax upon amounts collected from the holders of certificates of insurance issued by a fraternal benefit society whose obligations it had assumed. ${ }^{71}$ The difficulty with this procedure lies in the extremely heavy burden it would thrust upon administrative officials. While the latter may be competent to ascertain when, on the whole, the activities of a former fraternal benefit society have so perceptibly altered as to justify reclassification, the variety and complexity of modern forms of insurance make difficult any differentiation between specific forms for purposes of taxation. Besides, most statutes provide for the taxation of income or premiums of insurance companies, not of insurance activities. ${ }^{72}$ In view of the rate readjustment necessitated by the imposition of unexpected taxes, however, it would seem only fair that no tax should be levied unless the insurance commissioner has first refused to license the insurer as a fraternal benefit society.

68. The broad powers of insurance commissioners are described in Patterson, TaE Insurance Consamssioner in the United States (1927) passin.

69. See, e.g., (1935) 43 Fraternal Field No. 10, p. 5 ; (1930) 41 Fratersial MoNITOR No. 8, p. 31.

70. See, e.g., (1930) 41 Fraternal Monitor No. 8, p. 31 ; People ex rel. Aforse v. Grand Lodge of Indep. Order of Vikings, 354 Ill. 447, 183 N. E. 448 (1933). See § 11 New York Conference Bill in Basye, Fraternat. Insuraxice (1919) 138.

71. Yeoman Mut. Life Ins. Co. v. Murphy, 275 N. W. 127 (Iowa 1937). See also United Mrutual Life Ins. Co. of Indianapolis v. State, 108 S. W. (2d) 484 (Arl: 1937).

72. See, e.g., Conn. Gen. Stat. 1930, § 1281-1284, Cum. Supp. 1935, §408c (P. A. 1935 , c. 204, §3). 
But the desirability of widening the scope of the insurance commissioner's discretion should not minimize the importance of the numerous problems awaiting a solution by the legislatures. The fraternals, fearful lest one breach in their tax exempt status might lead to eventual wholesale change, have thus far mustered sufficient strength to defeat most of the contemplated legislation..$^{73}$ But an accentuation of present tendencies may undermine their influence. As a preliminary step, the legislatures might specify more rigid requirements to be satisfied by fraternal benefit societies in order to obtain tax exemptions. For example, in an important recent decision enjoining an insurance commissioner from collecting back taxes against fraternals, the court conceded that "if we were the New Mexico Legislature, we would pay close heed to" the arguments of the insurance commissioner. ${ }^{74}$ The New Mexico Legislature immediately followed this lead by amending its tax exemption of fraternal benefit societies to include only those which issue certificates or benefits strictly in accordance with fraternal benefit law, which limit their membership to members of one religious faith or hazardous occupation, which do not employ paid solicitors or salesmen, and which do not solicit insurance applications from the general public. ${ }^{7 \sigma}$

These narrow avenues of legislation deal only with the limited problem of differentiating fraternal insurance from its old line counterpart so as to avoid discrimination between essentially similar activities. But the anomalous complexities of fraternal insurance suggest the need for a more thoroughgoing reformulation of principles of insurance taxation which will take account of the social function of insurance without at the same time depriving the state of its revenues. Regardless of the ultimate determination of the taxable status of fraternal insurance, it is apparent that the present criteria are clumsy, arbitrary, and outmoded. There is nothing inherent in the lodge system or its attendant ritual which should clothe any fraternal activities with an aura of sanctity; yet that is the chief basis for Federal Income Tax exemption $^{76}$ and a major requirement for state tax exemption. ${ }^{77}$

73. See note 58 , supra.

74. Modern Woodmen of America v. Casados, 17 F. Supp. 763 (D. N. M. 1937).

75. The constitutionality of this statute was upheld in Woodmen of the World $v$. Casados, 21 F. Supp. 989 (D. N. M. 1938).

Similarly, Alabama attempted to tax only fraternal insurance which resembled old line insurance. For a history of the resultant litigation, see (1932) 40 Fraternal Field No. 2, p. 15. This statute was declared unconstitutional in State v. Praetorians, 226 Ala. 259, 146 So. 411 (1933). As an addition to the usual tax exempt provision, the following section had been proposed: "But whenever any fraternal benefit society issues policies of life insurance based on the adequate rate plan or provided by the statutes of any state ... then such societies shall pay to the state $1 \%$ of all premiums on such policies or contracts issued to citizens of this state." 226 Ala. 259, 260, 146 So. at 412.

76. Under the Federal Revenue Act exemption is granted to "Fraternal beneficiary societies, orders, or associations (A) operating under the lodge system or for the exclusive benefit of the members of a fraternity itself operating under the lodge system; and (B) providing for the payment of life, sick, accident or other benefits to the members of such 
More realistic criteria for demarcation of the lines of taxability would be (1) non-profit operation, and (2) the furnishing of low cost insurance. Adoption of the first test is mirrored in many state statutes which exempt nonprofit associations from various types of taxes. Behind this exemption is the policy of encouraging beneficial cooperative endeavor. Insofar as fraternals are run without profit, they should be eligible for exemption on the same basis as cooperatives, ${ }^{78}$ labor unions, ${ }^{70}$ and religious organizations. ${ }^{89}$ Furthermore, the glaring deficiency in insurance protection of Americans in the lower income brackets ${ }^{81}$ suggests that the most desirable criterion is the adaptability of the insurance to the needs of this major segment of the population. Most insurance schemes now catering to wage-earners pay for little more than the funeral expenses and leave the deceased's family with scant means of support. ${ }^{82}$ In addition, the small principal amount of the policies, the difficulties

society, order, or association or their dependents." 48 STAT. 703, 26 U. S. C. 103 (3) (1934).

"The absence of profit in the operation of the association is not the criterion, but the want of a fraternal side and object which it is in some measure organized to promote" Commercial Travelers' Life \& Accident Ass'n v. Rodway, 235 Fed. 370 at 375 (N. D. Ohio 1913). See also Bankers and Planters Mutual Insurance Ass'a v. Walker, 279 Fed. 53, 55 (C. C. A. 8th, 1922). For an elaboration of the lodge requirement, see I. T. 1516, I -2 Cuss. BULI 180 (1922). Although this feature need not predominate, it must be present. Furthermore, the lodge must be "active," not merely theoretical. Western Funeral Benefit Ass'n v. Hellmich, 2 F. (2d) 367 (E. D. Mro. 1924); Appeal of Philadelphiz \& Reading Relief Ass'n, 4 B. T. A. 713 (1926). But cf. Y. M. C. A. Retirement Fund, Inc. v. Commissioner of Internal Revenue, 18 B. T. A. 139 (1929).

77. See typical definition of fraternal benefit society, supra note 5. The same basis of distinction obtains in granting exemption from general insurance laws. E.g., a postal clerk association is treated as an ordinary insurance company because it had no initiatory ceremony or ritualistic form of work. Young v. Ry. Mail Ass'n, 126 Afo. App. 325, 103 S. W. 557 (1907). Labor unions may be treated differently. Corbett v. Mills Wagon Drivers Union, Local No. 603, 84 S. W. (2d) 377 (110. 1935). But cf. Brotherhood of Rr. Trainmen v. Woods, $256 \mathrm{Ky} .613,76 \mathrm{~S}$. W. (2d) 911 (1934). In American Insurance Union v. Lowry, 62 F. (2d) 209 (C. C. A. 5th, 1933), cert. den., 289 U. S. 745 (1933), one ground for refusing to call the defendant a fraternal banefit society was that the insurance agency contract contained no reference to "maling members, establishing chapters or lodges, giving grips and passwords, or to any fraternal or charitable object." For the various state criteria, see 1 Coucr, Cycropeda of Ixsurasicz LAw (1929) $\S \S 253$, $253 \mathrm{a}$ and cases and statutes cited.

78. Exemption of cooperatives from income tax is only partial. Kerr, Comfaralive Retailing Costs of Colwumers' Cooperatives (1937) 191 Awnals 113, 119. See tabulation in Consumers' Project, The Legal. Structure of Consuzrers's Coofezatife Socteties (1937) 200.

79. Labor unions enjoy universal exemption from income taxation. See, c.g., 48 Stat. 700, 26 U. S. C. 101 (1) (1934). See Parker, Benenctal Activites of Azrencalt Trade Unions (U. S. Bureau of Labor Statistics Bull. No. 465, 1928).

80. Religious organizations are also everywhere exempt from taxation. See, e.g., 48 StAT. 700,26 U. S. C. 101 (b) (1934).

81. See Fuller, The Special Nature of the Wage-Eamer's Life Insuranee Problem

(1935) 2 Law \& Contearp. Prob. 10.

82. Ibid. 